\begin{tabular}{|c|c|c|}
\hline & JSI 9 (1) (2020) & (1) \\
\hline$\sqrt{2}$ & Jurnal Sastra Indonesia & 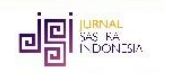 \\
\hline UNNES & http://journal.unnes.ac.id/sju/index.php/jsi & 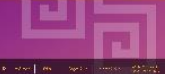 \\
\hline
\end{tabular}

\title{
UJARAN KEBENCIAN FACEBOOK TAHUN 2017-2019
}

\section{Devita Indah Permatasari $^{\bowtie 1}$ dan Subyantoro ${ }^{2}$}

Program Studi Sastra Indonesia, Jurusan Bahasa dan Sastra Indonesia, Fakultas Bahasa dan Seni, Universitas Negeri Semarang, Indonesia

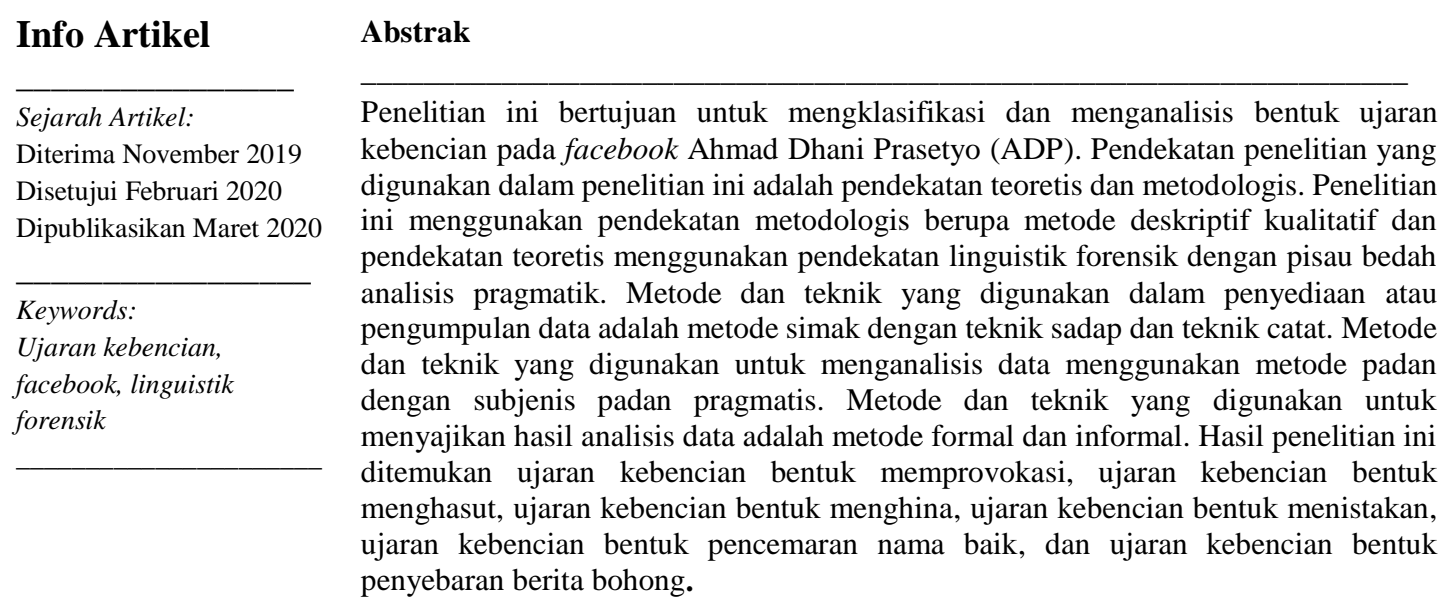

\begin{abstract}
This study aimed to (1) classify and analyze the types of utterances of hate speech on Ahmad Dhani Prasetyo's (ADP) Facebook account. The research approaches used in this study were theoretical and methodological approach. This study used a methodical approach in form of a qualitative descriptive method and theoretical approach used a forensic linguistic approach with a scalpel pragmatic analysis. The methods and techniques used in the provision or collection of the data were scrutinizing method by using extracting technique and note-taking technique. The methods and techniques used in analyzing the data used the equivalence method with pragmatic equivalence sub type. The methods and techniques used to present the results of the data analysis were formal and informal methods. In the results of this study, illocutionary utterances of hate speech in form of provoking, illocutionary utterances of hate speech in form of inciting, illocutionary utterances of hate speech in form of insulting, illocutionary utterances of hate speech in form of defamation, illocutionary utterances of hate speech in form of defamation and into utterances of hate speech in form of the false news spreading.
\end{abstract}

(C) 2020 Universitas Negeri Semarang

\footnotetext{
Alamat korespondensi:

Gedung B1 Lantai 1 FBS Unnes

Kampus Sekaran, Gunungpati, Semarang, 50229

E-mail: ugikbcahyono@gmail.com
}

ISSN 2252-6315

E-ISSN 2685-9599 


\section{PENDAHULUAN}

Bahasa dalam berkomunikasi mempunyai dampak yang sangat luas, bahasa mempunyai dampak pada kehidupan manusia. Subyantoro (2019: 37) mengatakan bahwa bahasa pada dasarnya sudah menyatu dengan kehidupan manusia. Manusia menyampaikan gagasan, ide, pikiran, harapan dan keinginan melalui bahasa. Penggunaan bahasa memiliki berbagai kepentingan dan fungsinya masing-masing. Bahasa digunakan oleh manusia untuk kepentingan pendidikan, budaya, agama, dan lain-lain.

Salah satu peran bahasa yang tengah menjadi sorotan adalah peran bahasa di bidang hukum. Peran bahasa di bidang hukum kini sudah menjadi sangat penting. Hal tersebut terlihat dari banyaknya para ahli bahasa yang dilibatkan untuk menangani sebuah kasus tertentu. Apabila biasanya suatu penyidikan terhadap sebuah kasus bertumpu pada aspekaspek di dalam dunia hokum, kini aspek dari segi bahasa sudah menjadi salah satu aspek yang bisa membantu dalam penyidikan sebuah kasus tertentu. Para ahli bahasa menggunakan ilmu kebahasaan (linguistik) untuk membantu menangani kasus hukum tertentu. Ilmu kebahasaan yang digunakan adalah ilmu linguistik forensik. Salah satu kajian linguistik forensik yang menarik adalah kajian terhadap kasus ujaran kebencian. Ujaran kebencian (hate speech) merupakan tindakan komunikasi yang dilakukan oleh individu atau kelompok tertentu dalam bentuk provokasi, hasutan, hinaan, penistaan, pencemaran nama baik, serta penyebaran berita bohong dalam aspek seperti ras, warna kulit, gender, etnis, cacat fisik, orientasi seksual, kewarganeraaan, agama, dan lain-lain.

Penelitian Lestari (2016) yang berjudul "Ungkapan Kebencian yang Muncul pada Fenomena Islamophobia di United Kingdom" mengungkapkan bahwa tuturan yang diujarkan seseorang membawa dampak bagi pendengarnya baik itu tersurat maupun tersirat. Bahkan suatu ujaran juga akan membuat seseorang diseret ke meja hijau lantaran dianggap meresahkan. Misalnya ujaran kebencian atau sering disebut hate speech yang marak diperbincangkan di Indonesia saat ini terkait akan wacana penindakan secara hukum bagi pelaku karena dianggap menyulut kebencian bagi kelompokkelompok tertentu

Dalam kajian Mapping and Analysing Hate Speech Online: Opportunities and Challenges for Ethiopia oleh Iginio Glagiordone, dkk (2014: 5) dijelaskan bahwa memang ujaran kebencian mempunyai keterkaitan yang kompleks dengan kebebasan berekspresi, hak-hak perorangan, kelompok dan kaum minoritas dan juga terkait dengan konsep-konsep martabat, kebebasan, persamaan, dan juga konteks. Ujaran kebencian dikatakan sebagai bagian dari kriminalitas kebencian. Hal ini dirumuskan sebagai aksi menghasut orang lain untuk membenci pihak tertentu, tidak hanya berdasarkan SARA, tetapi juga bisa berdasarkan disabilitas atau orientasi seksual. Ujaran kebencian di media sosial khususnya facebook menjadi kasus yang akhirakhir ini sering terjadi dengan pelaku mulai dari masyarakat awam, artis (public figure) sampai pejabat.

Adapun sasaran ujaran kebencian juga beragam, dari pelajar sampai, masyarakat luas dan pejabat. Tidak jarang ujaran kebencian menyasar lebih dari satu identitas yang melekat dalam diri objeknya. Menurut Andersson dan Hirsch (2008) menjelaskan bahwa semua bentuk ujaran kebencian baik melalui pesan teks, siaran radio, selebaran, dan yang diucapkan menimbulkan konflik karena ujaran kebencian memprovokasi orang untuk menggunakan kekerasan, memancing permusuhan antargrup dan melukai banyak orang yang mendengarnya. Adanya ujaran yang mengandung emosi negatif seperti kebencian dan hinaan. Sehingga kajian mengenai ujaran kebencian ini telah banyak dikaji dalam perspektif hukum untuk menemukan batasan-batasan akan kebebasan berbicara dan berekspresi. Ujaran kebencian dalam kajian linguistik dapat menemukan tindak tutur dalam kajian pragmatik, pola-pola kalimat, kosakata serta gaya bahasa yang cenderung dianggap menjadi ujaran kebencian.

Hal itu menjadi menarik untuk diteliti oleh penulis agar mengetahui bagaimana tindak tutur dalam kajian pragmatik terhadap ujaran kebencian itu, karena tuturan dapat berdampak bagi pendengar dan pembacanya. Hal tersebut juga disampaikan oleh Raphael Cohen-Almagor melalui Gagliardone (2014: 9) yang mendefinisikan ujaran kebencian merupakan ujaran yang bermotif jahat yang mengekspresikan diskriminasi, intimidasi, penolakan, praduga orang perseorangan atau sekelompok orang yang berkaitan dengan isu gender, ras, agama, etnik, warna, negara asal, ketidakmampuan atau orientasi seksual.

Sejalan dengan itu, Prima Angkupi (2014) membahas tentang kejahatan melalui media sosial elektronik di Indonesia berdasarkan Peraturan Perundang-undangan saat ini. Mangantibe (2016) membahas tentang ujaran kebencian dalam Surat Edaran Kapolri Nomor: 
$\mathrm{SE} / 6 / \mathrm{X} / 2015$ tentang penanganan ujaran bebencian (Hate Speech). Penelitian Saifullah (2016) yang berjudul "Analisis Teks Tanggapan Pengguna Internet Terhadap Teks Media Siber yang Berdampak Hukum (Kajian Linguistik Forensik Berbasis Semiotik-Pragmatik)" menyebutkan bahwa kehadiran media siber di ruang virtual telah mendorong terjadinya relasi kuasa antara media dan publik semakin setara. Atas dasar itu, kajian ini berusaha menelusuri dan memperlihatkan bagaimana kecenderungan tindak tutur anarkis itu terjadi dalam praktik berbahasa di media siber yang dilakukan oleh para pengguna internet dalam mengungkapkan tanggapannya terhadap teks berita yang dikonstruksi media. Selain itu juga selaras dengan penelitian yang dilaksanakan oleh Nugraheni (2017) mengenai ujaran kebencian pada wacana Debat Cagub Cawagub DKI Jakarta 2017 dan implementasinya. Octaviani (2017) juga membahas tentang ungkapan kebencian pada tuturan haters di akun instagram Basuki BTP dan relevansinya terhadap pembelajaran bahasa Indonesia di SMA. Penelitian Widodo (2017) yang berjudul "Ujaran Kebencian terhadap Pejabat Publik dalam Media Sosial: Kajian Pragmatik Pendekatan Gender". Penelitian ini bertujuan mengidentifikasi perbedaan jenis, mendeskripsikan strategi dan mendeskripsikan bentuk ujaran kebencian oleh laki-laki dan perempuan terhadap pejabat publik di media sosial. Jenis penelitian ini adalah penelitian kualitatif. Penelitian Lukman menghasilkan beberapa bentuk ujaran kebencian yang ada pada pejabat publik di media sosial.

Penelitian Zahrotunnisa (2016) melakukan penelitian yang berjudul "Tindak Tutur dalam Sidang Perkara Pidana di Pengadilan Negeri Jakarta Timur". Penelitian yang dilakukan oleh Zahrotunnisa bertujuan untuk mengetahui tindak tutur dalam sidang perkara pidana di Pengadilan Negeri Jakarta Timur. Hasil penelitian Reza menunjukkan bahwa tindak tutur dalam sidang perkara pidana di Pengadilan Negeri Jakarta Timur didominasi oleh hakim. Tindak lokusi yang paling banyak muncul adalah dalam bentuk kalimat deklaratif sebanyak 55 tuturan, kalimat interogatif sebanyak 37 tuturan, dan kalimat imperatif sebanyak 17 tuturan. Linawati (2017) melakukan penelitiannya yang berjudul "Tindak Tutur Ujaran Kebencian dalam Komentar Pembaca pada Surat Kabar Online Tribunnews.com".

Hasil penelitiannya dalam komentar pembaca pada surat kabar online tribunnews.com terdapat bentuk ujaran kebencian berupa penghinaan, pencemaran nama baik, penistaan, perbuatan tidak menyenangkan, memprovokasi, dan menghasut. Bentuk ujaran kebencian berupa penghinaan banyak ditemukan dalam komentar pembaca surat kabar online tribunnews.com. Salutfiyanti (2018) penelitiannya yang berjudul "Analisis Ujaran Kebencian dalam Komentar Warganet pada Akun Instagram Obrolan Politik" mengkaji aspek pragmatik, yaitu mengenai ungkapan tuturan pembaca pada komentar dalam akun instagram obrolan politik.

Penelitian Salutfiyanti bertujuan untuk menjelaskan ungkapan-ungkapan ketidaksukaan atau kebencian yang dilontarkan oleh pembaca yang kontra dengan topik politik yang dibahas, menunjukkan unsur pelanggaran kesantunan. Ningrum, dkk (2018) dalam penelitiannya yang berjudul "Kajian Ujaran Kebencian di Media Sosial" mempunyai tujuan untuk mendeskripsikan bentuk tindak ujaran kebencian di media sosial serta jenis tindak tutur ilokusi pada komentar netizen di facebook. Hasil dari penelitian Ningrum, dkk adalah bentuk ujaran kebencian penghinaan, menghasut, provokasi politik, pencemaran nama baik, penistaan agama, dan menyebarkan berita bohong (hoax).

Dalam penelitian Ningrum, dkk terdapat tuturan paling banyak ditemukan bentuk ujaran kebencian penistaan agama dan penghinaan bersifat mencela. Subyantoro (2019) dalam jurnalnya yang berjudul "Linguistik Forensik: Sumbangsih Kajian Bahasa dalam Penegakan Hukum" mengemukakan bahwa bahasa dipandang sebagai alat yang praktis dan efektif dalam memegang peranan yang penting untuk menciptakan dan melaksanakan hukum dalam suatu masyarakat. Subyantoro menyebutkan bahwa ada tiga bidang utama yang menjadi fokus kajian linguistik forensik, yaitu (1) bahasa sebagai produk hukum; (2) bahasa dalam proses peradilan; dan (3) bahasa sebagai alat bukti. Bentuk-bentuk Ujaran Kebencian (Hate Speech) dapat berupa tindak pidana yang diatur dalam Kitab Undang-Undang Hukum Pidana (KUHP) dan ketentuan pidana lainnya di luar KUHP, antara lain, memprovokasi, menghasut, menghina, penistaan, pencemaran nama baik, perbuatan tidak menyenangkan, penyebaran berita bohong.

Arsel (2018) dalam penelitannya yang berjudul "Proses Penyidikan Terhadap Pelaku Tindak Pidana Menyebarkan Ujaran Kebencian melalui Facebook" bertujuan untuk mengetahui latar belakang penyidik dalam melakukan penyidikan terhadap pelaku tindak pidana penyebaran ujaran kebencian melalui facebook, serta untuk mengetahui bagaimana proses penyidikan terhadap pelaku tindak pidana 
menyebarkan ujaran kebencian melalui facebook. Febriyanti (2018) penelitiannya yang berjudul "Analisis Faktor Penyebab Pelaku Melakukan Ujaran Kebencian (Hate Speech) dalam Media Sosial" bertujuan mendeskripsikan faktor penyebab pelaku melakukan ujaran kebencian dalam media sosial serta upaya untuk menanggulangi pelaku yang melakukan ujaran kebencian dalam media sosial.

Dapat diketahui bahwa ujaran kebencian merupakan ungkapan yang secara hukum bisa dimintai pertanggungjawabannya karena merupakan tindak kejahatan. Dengan dilakukan penelitian tindak tutur ilokusi ujaran kebencian di facebook ini diharapkan paling tidak mampu memberikan sumbangsih ihwal perkembangan teori linguistik forensik terkait ujaran kebencian. Hasil penelitian ini juga diharapkan dapat memberikan gambaran atau acuan bagi orang tua dan pendidik untuk mengajarkan bagaimana bertutur dengan baik di media sosial agar tidak merugikan orang atau kelompok lain.

\section{METODE PENELITIAN}

Penelitian ini menggunakan rancangan penelitian deskriptif kualitatif. Adapun pendekatan yang digunakan adalah pendekatan teoretis dan pendekatan metodologis. Pendekatan teoretis menggunakan linguistik forensik. Data dalam penelitian ini berupa penggalan-penggalan tuturan ilokusi yang diduga mengandung ujaran kebencian yang dituturkan oleh ADP di facebook. Pengumpulan data dalam suatu proses penelitian sangat memerlukan adanya sumber data. Sumber data dalam penelitian ini adalah tuturan postingan facebook ADP yang ada dari tahun 2017-2019.

Metode simak yang dilakukan di penelitian ini dengan cara melakukan penyimakan tuturan ADP di facebooknya. Penyimakan dapat dilakukan melalui media sosial facebook. Teknik dasar yang digunakan adalah teknik sadap. Kemudian dilanjutkan dengan teknik lanjutan yaitu, teknik simak sekaligus bersamaan dengan teknik catat. Metode analisis data yang digunakan dalam jenis penelitian deskriptif kualitatif ini menggunakan metode padan subjenis pragmatis dengan alat penentunya adalah penggalan teks wacana. Metode padan yang digunakan yaitu metode pragmatis. Teknik dasar yang digunakan adalah Teknik Pilah Unsur Penentu (PUP). Selanjutnya teknik dasar dilanjutkan dengan Teknik Hubung Banding Menyamakan Hal Pokok (HSBP). Dalam penelitian ini metode yang digunakan untuk penyajian data ialah metode informal.
Metode penyajian informal digunakan untuk mengungkap penggunaan bahasa untuk memahami bagaimana bentuk ujaran kebencian, bagaimana satuan lingualnya dan faktor-faktor yang mempengaruhi ujaran kebencian tersebut dituturkan.

\section{HASIL DAN PEMBAHASAN}

\section{Hasil Penelitian}

Ujaran kebencian yang ditemukan dalam faebook penutur merupakan bentuk tuturan yang mengandung cemoohan, sindiran, penghinaan, pencemaran nama baik, penistaan dan penyebaran berita bohong yang ditujukan dengan seseorang, beberapa orang bahkan kelompok-kelompok tertentu. Berdasarkan hasil penelitian dari 34 data, terdapat enam bentuk ujaran kebencian yang ditemukan dalam penelitian ini yaitu (1) ujaran kebencian bentuk memprovokasi, (2) ujaran kebencian bentuk menghasut, (3) ujaran kebencian bentuk penghinaan, (4) ujaran kebencian bentuk penistaan, (5) ujaran kebencian bentuk pencemaran nama baik, (6) ujaran kebencian bentuk penyebaran berita bohong. Berikut dijabarkan karakter-karakter ujaran kebencian.

\section{Pembahasan}

Bentuk ujaran kebencian yang ditemukan dalam facebook ADP yaitu, memprovokasi, menghasut, menghina, penistaan, pencemaran nama baik, penyebaran berita bohong. Bentukbentuk ujaran kebencian tersebut sebagai berikut.

\section{Ujaran Kebencian Bentuk Memprovokasi}

Menurut KBBI memprovokasi artinya adalah suatu perbuatan yang dilakukan untuk membangkitkan kemarahan dengan cara menghasut, memancing amarah, kejengkelan dan membuat orang yang terhasut mempunyai pikiran negatif dan emosi. Ujaran kebencian memprovokasi pada facebook ADP dapat diuraikan sebagai berikut.

Ahmad Dhani Prasetyo
BCORDING TO ADP
BY AhmadDhani
PARA PENDUKUNG PENGEDAR NARKOTIKA ADALAH
ANJING YANG HARUS DI BAKAR
PARA PEMBELA KORUPTOR ADALAH CECUNGUK
YANG HARUS DI GANTUNG
PARA PENDUKUNG PEMERKOSA ANAK KECIL ADALAH
BANGSAT YANG HARUS DI GOROK
PARA PENDUKUNG PEMBELA PENISTA AGAMA
ADALAH BAJINGAN YANG PERLU DI LUDAHI
MUKANYA
ADA YANG MARAH DENGAN PENDAPAT SAYA???

Hasil penelitian terhadap ADP menunjukkan kesesuaian dengan hasil penelitian Linawati (2017) tentang tindak tutur ujaran kebencian dalam komentar pembaca pada surat 
kabar online tribunnews.com. Ujaran kebencian menghasut merupakan ujaran yang penutur mempunyai maksud membuat orang bernafsu untuk marah terhadap orang atau kelompok tertentu. Dalam upaya menghasut tidak perlu dilakukan secara berapi-api dan tidak perlu perkataan yang bersifat membakar kemauan, namun tidak mengakibatkan tindakan tertentu. Dalam tuturan tersebut penutur berusaha menghasut pembaca yang netral bernafsu untuk marah terhadap pernyataan penutur yang menganggap bahwa rezim ini adalah rezim hoax, namun penutur tidak berapi-api dalam menyampaikannya. Terdapat tindak tutur ilokusi di dalamnya yang terlihat menghasut agar para pembaca marah kepada JKW yang dianggap selalu hoax karena belum menepati janji-janjinya waktu kampanye.

Berdasarkan hasil analisis data, ujaran kebencian bentuk mempovokasi, ditemukan tiga jenis karakter memprovokasi dalam penelitian ini yaitu, karakter ujaran kebencian bentuk memprovokasi dengan maksud membentuk pikiran pembaca agar menyetujui apa yang dituturkan, ujaran kebencian dengan bentuk memprovokasi yang berdampak pada diskriminasi pada pembeda golongan, dan ujaran kebencian bentuk memprovokasi dengan dorongan emosi dari penutur yang berlebihan.

\section{Ujaran Kebencian Bentuk Menghasut}

Menurut R. Soesilo menghasut artinya mendorong, mengajak, membangkitkan atau membakar semangat orang supaya berbuat sesuatu. Dalam kata "menghasut" tersimpul sifat "dengan sengaja". Menghasut itu lebih keras daripada "memikat" atau "membujuk" akan tetapi bukan "memaksa". Ujaran kebencian menghasut pada facebook ADP dapat diuraikan sebagai berikut.

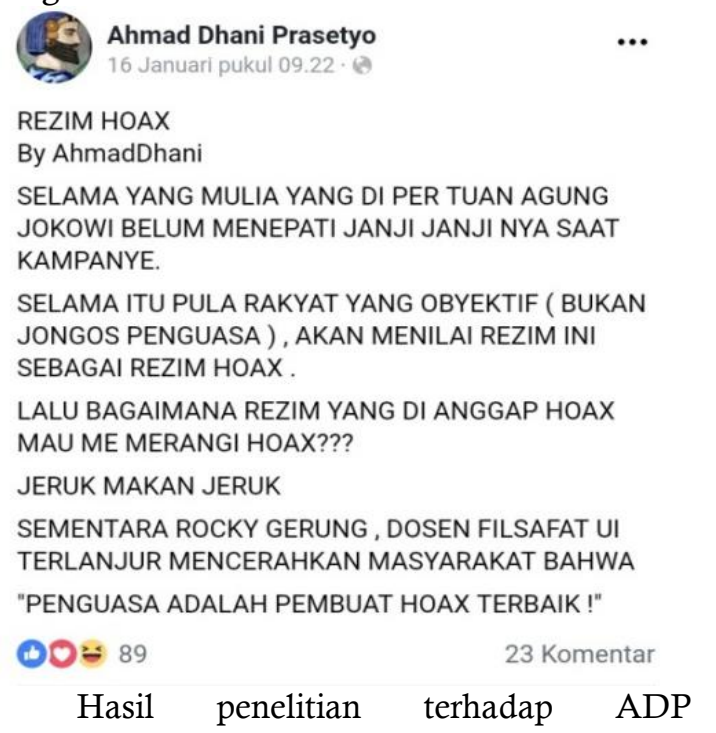

menunjukkan kesesuaian dengan hasil penelitian Syafyahya (2018) tentang ujaran kebencian dalam bahasa Indonesia: kajian bentuk dan makna. Ujaran kebencian menghasut merupakan ujaran yang penutur mempunyai maksud membuat orang bernafsu untuk marah terhadap orang atau kelompok tertentu. Dalam upaya menghasut tidak perlu dilakukan secara berapiapi dan tidak perlu perkataan yang bersifat membakar kemauan, namun tidak mengakibatkan tindakan tertentu. Dalam tuturan tersebut penutur berusaha menghasut pembaca yang netral bernafsu untuk marah terhadap pernyataan penutur yang menganggap bahwa rezim ini adalah rezim hoax, namun penutur tidak berapi-api dalam menyampaikannya. Terdapat tindak tutur ilokusi di dalamnya yang terlihat menghasut agar para pembaca marah kepada JKW yang dianggap selalu hoax karena belum menepati janji-janjinya waktu kampanye. Berdasarkan hasil analisis data tindak tutur ujaran kebencian bentuk menghasut, ditemukan satu jenis karakter menghasut dalam penelitian ini yaitu, karakter ujaran kebencian bentuk menghasut yang berusaha untuk membuat orang lain bernafsu untuk marah terhadap orang atau kelompok tertentu.

\section{Ujaran Kebencian Bentuk Menghina}

Menurut R. Soesilo dalam bukunya yang berjudul Kitab Undang- UndangHukum Pidana (KUHP) serta Komentar-Komentarnya Lengkap Pasal Demi Pasal dalam penjelasan Pasal 310 KUHP, menerangkan bahwa: menghina adalah Menyerang kehormatan dan nama baik seseorang. Yang diserang ini biasanya merasa malu. Objek penghinaan adalah berupa rasa harga diri atau martabat mengenai kehormatan dan mengenai nama baik orang baik bersifat individual ataupun komunal (kelompok). Ujaran kebencian menghina pada facebook ADP dapat diuraikan sebagai berikut.

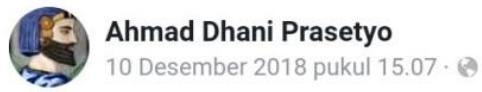

\section{REVOLUSI CACAT MENTAL}

Adalah

TIDAK MENEPATI JANJI JANJI SAAT KAMPANYE TAPI NEKAT MAU NYAPRES LAGI..

TIDAK PUNYA RASA MALU DALAM DIRINYA.

AhmadDhani.

75 Komentar 9 Kali Dibagikan
Hasil penelitian terhadap ADP

menunjukkan kesesuaian dengan hasil penelitian Ubaidillah (2018) yang berjudul tindak tutur direktif ujaran kebencian di media sosial di 
Indonesia. Menurut Aulia tuturan yang dapat menimbulkan konflik sosial merupakan ujaran kebencian bentuk penghinaan. Pada tuturan merupakan kritikan yang menghina karena terdapat frasa "cacat mental" yang berarti kelainan mental dan/atau tingkah laku, baik cacat bawaan maupun akibat dari penyakit. Tuturan tersebut termasuk tuturan menghina karena dapat menyakiti perasaan seseorang tersebut. Pada kenyataannya kondisi mental JKW tidak seperti yang diungkapkan oleh penutur. Penutur menyebutkan bahwa JKW saat ini juga tidak mempunyai rasa malu karena mencalonkan diri sebagai presiden untuk kedua kalinya, padahal janji-janji kampanye belum terealisasikan semuanya.

Berdasarkan hasil analisis data tindak tutur ujaran kebencian bentuk menghina, ditemukan tiga jenis karakter menghina dalam penelitian ini yaitu, karakter ujaran kebencian bentuk menghina dengan maksud menyerang kehormatan seseorang sehingga yang diserang merasa malu, ujaran kebencian bentuk menghina yang bermaksud menjatuhkan nama baik dan kehormatan seseorang, dan ujaran kebencian bentuk menghina yang menimbulkan konflik sosial.

\section{Ujaran Kebencian Bentuk Penistaan}

Penistaan adalah suatu perkataan, perilaku, tulisan, ataupun pertunjukan yang dilarang karena dapat memicu terjadinya tindakan kekerasan dan sikap prasangka entah dari pihak pelaku pernyataan tersebut ataupun korban dari tindakan tersebut. Ujaran kebencian penistaan pada facebook ADP dapat diuraikan sebagai berikut.

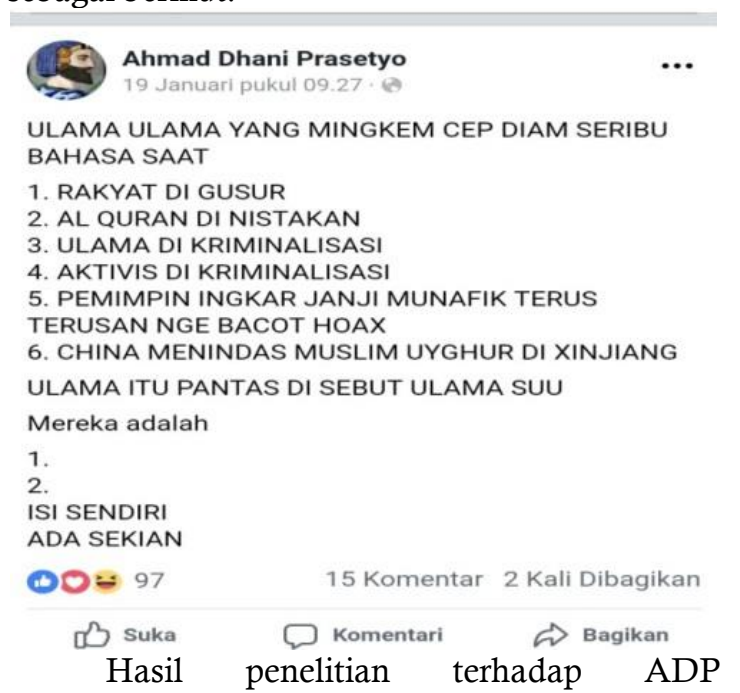

menunjukkan kesesuaian dengan hasil penelitian Sari (2019) mengenai ujaran kebencian pada wacana talkshow Indonesia Lawyers Club. Ujaran kebencian bentuk penistaan merupakan ujaran yang mempunyai maksud untuk merendahkan nama baik seseorang atau kelompok. Tindakan merendahkan dapat dilakukan dengan tuduhan melakukan tindakan atau suatu hal yang berbau agama. Tuturan tersebut termasuk bentuk ujaran kebencian penghinaan yang ditujukan untuk menyerang harga diri dari kelompok tertentu yang ditujukan untuk menyerang nama baik yang disebutkan dengan ciri-ciri tersebut (Ulama SUU). Terdapat kata munafik pada ujaran yang berarti tidak jujur dan frasa al quran dinistakan yang berarti hina kitab suci umat Islam dihina. Ujaran bermaksud menyerang nama baik kelompok tertentu dengan menyebut sebagai orang yang tidak jujur dan orang yang menistakan kitab suci umat Islam.

Berdasarkan hasil analisis data tindak tutur ujaran kebencian bentuk penistaan, ditemukan satu jenis karakter menistakan dalam penelitian ini yaitu, karakter yang mempunyai maksud untuk merendahkan nama baik seseorang atau kelompok yang melakukan tindakan suatu hal yang berbau agama.

\section{Ujaran Kebencian Bentuk Pencemaran Nama} Baik

Pengertian Pencemaran Nama Baik dalam KUHP dikenal juga pencemaran nama baik (defamation) ialah tindakan mencemarkan nama baik atau kehormatan seseorang melalui cara menyatakan sesuatu baik secara lisan maupun tulisan. Ujaran kebencian pencemaran nama baik pada facebook ADP dapat diuraikan sebagai berikut.

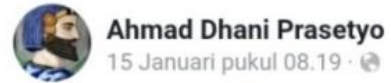

\section{JOKOWINOMIC \\ 1. PERBANYAK HUTANG LAGI DAN LAGI \\ 2. PAJAKIN RAKYAT LAGI DAN LAGI \\ 3. JUAL ASET LAGI DAN LAGI. \\ SALAM DUA PERIODE NYUNGSEP

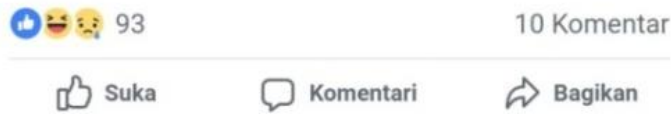

Hasil penelitian terhadap ADP menunjukkan kesesuaian dengan hasil penelitian Ningrum (2018) mengenai kajian ujaran kebencian di media sosial. Tuturan ujaran kebencian bentuk pencemaran nama baik merupakan tuturan yang mengandung unsur yang dapat menyebabkan konflik sosial yang dapat menyebabkan benturan fisik atau perseteruan yang berdampak luas dan menimbulkan ketidakamanan dan disintegrasi sosial, sehingga mengganggu stabilitas nasional dan menghambat pembangunan. Penanda lingual bentuk mencemarkan nama baik dalam 
tuturan tersebut yaitu "salam dua periode nyungsep". Pada ujaran tersebut terdapat kata nyungsep. Nyungsep merupakan kosakata bahasa Jawa. Nyungsep dalam bahasa Indonesia mempunyai arti jatuh ke depan. Penutur memberitahukan bahwa dua periode kepemimpinan JKW akan jatuh perlahan di berbagai sektor.

Berdasarkan hasil analisis data tindak tutur ujaran kebencian bentuk pencemaran nama baik, ditemukan dua jenis karakter mencemarkan nama baik dalam penelitian ini yaitu, karakter yang mempunyai maksud untuk menyerang dan merugikan nama baik dan kehormatan seseorang dan karakter yang mengandung unsur yang dapat menyebabkan konflik sosial yang dapat menyebabkan benturan fisik atau perseteruan yang berdampak luas.

\section{Ujaran Kebencian Bentuk Penyebaran Berita Bohong}

Menurut R.Soesilo Penyebaran Berita Bohong yaitu menyiarkan berita atau kabar dimana ternyata kabar yang disiarkan itu adalah kabar bohong, yang dipandang sebagai kabar bohong tidak saja memberitahukan suatu kabar kosong, akan tetapi juga menceritakan secara tidak betul suatu kejadian. Ujaran kebencian penyebaran berita bohong pada facebook ADP dapat diuraikan sebagai berikut.

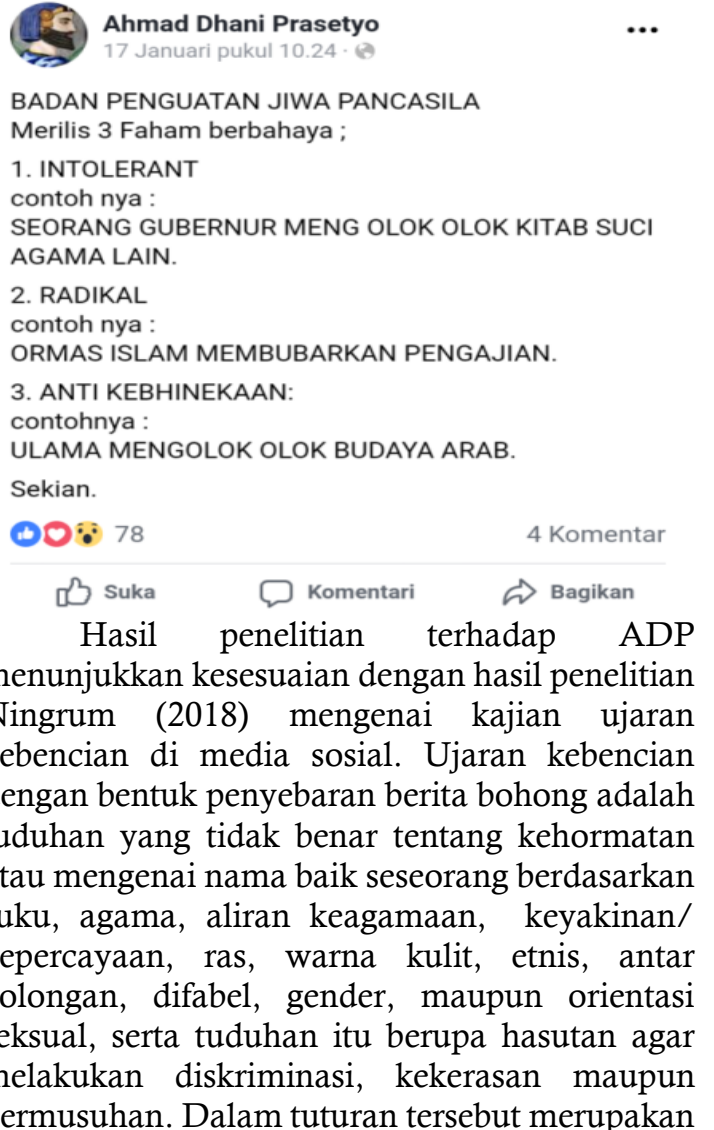

penyebaran berita bohong karena tidak ada badan di dalam pemerintahan yang bernama "Badan Penguatan Jiwa Pancasila", dalam pemerintahan hanya terdapat Badan Pembinaan Ideologi Pancasila yang disingkat BPIP. Jelas penutur menyebarkan berita yang tidak benar, karena penutur juga menyebutkan bahwa terdapat tiga paham berbahaya yang dirilis Badan Penguatan Jiwa Pancasila. Tuturan tersebut menimbulkan ketakutan jika masyarakat tidak paham mengenai hal ini. Hal ini penutur dengan sengaja menuduh pemerintah dengan bukti yang tidak pasti agar reputasi pemerintah buruk di mata masyarakat. Tuturan ini berdampak pada konflik sosial yang dapat menimbulkan kekerasan maupun perseteruan

Berdasarkan hasil analisis data tindak tutur ujaran kebencian bentuk penyebaran berita bohong, ditemukan satu jenis karakter menyebarkan berita bohong dalam penelitian ini yaitu, karakter tuduhan yang tidak benar tentang kehormatan atau mengenai nama baik seseorang berdasarkan suku, agama, aliran keagamaan, keyakinan/kepercayaan, ras, warna kulit, etnis, antar golongan, difabel, gender, maupun orientasi seksual, serta tuduhan itu berupa hasutan agar melakukan diskriminasi, kekerasan maupun permusuhan.

Berdasarkan karakter-karakter tersebut, dapat disimpulkan melalui tabel bentuk-bentuk ujaran kebencian paling banyak digunakan adalah sebagai berikut. Adapun berdasarkan realisasi bentuk ujaran kebencian facebook ADP diperoleh hasil penelitian sebagai berikut.

Tabel 1. Persentase Ujaran Kebencian

\begin{tabular}{|l|l|c|c|}
\hline No & \multicolumn{1}{|c|}{$\begin{array}{c}\text { Jenis Ujaran } \\
\text { Kebencian }\end{array}$} & Frekuensi & Persentase \\
\hline 1 & Memprovokasi & 7 & $20,59 \%$ \\
\hline 2 & Menghasut & 7 & $20,59 \%$ \\
\hline 3 & Menghina & 7 & $20,59 \%$ \\
\hline 4 & Penistaan & 1 & $2,94 \%$ \\
\hline 5 & $\begin{array}{l}\text { Pencemaran Nama } \\
\text { Baik }\end{array}$ & 4 & $11,76 \%$ \\
\hline 6 & $\begin{array}{l}\text { Penyebaran Berita } \\
\text { Bohong }\end{array}$ & 8 & $23,53 \%$ \\
\hline \multicolumn{2}{|l|}{ Jumlah } & 34 & $100 \%$ \\
\hline
\end{tabular}

Berdasarkan data pada tabel 1 tersebut terlihat bahwa realisasi ujaran kebencian yang tertinggi $23,53 \%$ berbentuk penyebaran berita bohong. Disusul ujaran kebencian bentuk memprovokasi, menghasut dan menghina sama- 
sama 20,59\%, bentuk pencemaran nama baik 12,10 dan penistaan 3\%. Berdasarkan karakteristik tersebut, dapat disimpulkan melalui tabel satuan linguistik ujaran kebencian. Adapun berdasarkan realisasi bentuk satuan linguistik pada ujaran kebencian facebook ADP diperoleh hasil penelitian sebagai berikut.

Tabel 2. Bentuk Ujaran Kebencian

\begin{tabular}{|c|c|c|c|}
\hline No & $\begin{array}{c}\text { Satuan } \\
\text { Linguistik } \\
\text { Ujaran } \\
\text { Kebencian }\end{array}$ & Frekuensi & Persentase \\
\hline 1 & Kata & 4 & $11,76 \%$ \\
\hline 2 & Frasa & 5 & $14,71 \%$ \\
\hline 3 & Klausa & 1 & $2,94 \%$ \\
\hline 4 & Kalimat & 13 & $38,24 \%$ \\
\hline 5 & Wacana & 11 & $32,35 \%$ \\
\hline & Jumlah & 34 & $100 \%$ \\
\hline
\end{tabular}

Berdasarkan data penelitian pada tabel 2 terlihat bahwa ujaran kebencian dalam bentuk kalimat sebanyak $38,24 \%$, dalam bentuk wacana $32,35 \%$, dalam bentuk frasa $14,71 \%$, dalam bentuk kata $11,76 \%$, dan yang paling sedikit dalam bentuk klausa 2,94\%.

\section{PENUTUP}

Simpulan

Berdasarkan pembahasan tersebut dapat disimpulkan dua hal berikut. Pertama, ditemukan enam bentuk ujaran kebencian dalam facebook ADP. Ujaran kebencian bentuk memprovokasi, bentuk menghasut, bentuk menghina, bentuk menistakan, bentuk pencemaran nama baik, dan bentuk penyebaran berita bohong.

Para peneliti bahasa diharapkan menjadikan penelitian ini sebagai referensi untuk dikembangkan lebih lanjut agar penelitian ini menjadi lebih sempurna dan menambah khazanah ilmu bahasa. Penulis berharap agar ada penelitian mendalam yang bisa membahas mengenai bahasa dari kajian linguistik forensik, khususnya yang berhubungan dengan ujaran kebencian.

\section{DAFTAR PUSTAKA}

Arsel, Zefanya Fredericus. (2018). Proses Penyidikan Terhadap Pelaku Tindak Pidana Menyebarkan Ujaran Kebencian Melalui Facebook. Skripsi. Unika Soegijapranata Semarang.

Febriyanti, Meri. (2018). Analisis Faktor Penyebab Pelaku Melakukan Ujaran Kebencian (Hate
Speech) dalam Media Sosial. Jurnal Penale, Vol. 6 No. 3.

Hirsch, Susan F. (2008). Putting Hate Speech in Context: Observation on Speech, Power, and Violenee in Kenya. George Mason University. Diakses tanggal 23 Maret 2019 https://www.ushmm.org/m/pdfs/20100423speech-power-violence-hirsch.pdf.

Iginio Glagiordone, dkk. 2014. Mapping and Analysing Hate Speech Online: Opportunities and Challenges for Ethiopia. Britania Raya: University of Oxford.

Kamus Besar Bahasa Indonesia Online. (2018).

Lestari, Dwi Puji. (2016). Ungkapan Kebencian yang Muncul pada Fenomena Islamophobia di United Kingdom. Tesis. Universitas Gajah Mada.

Linawati. (2017). "Tindak Tutur Ujaran Kebencian dalam Komentar Pembaca pada Surat Kabar Online Tribunnews.com". Skripsi. Universitas Negeri Yogyakarta.

Mangantibe, Veisy. (2016). Ujaran Kebencian dalam Surat Edaran Kapolri Nomor: SE/6/X/2015 Tentang Penanganan Ujaran Kebencian (Hate Speech). Jurnal Lex Crimen, Vol. 5, No. 1.

Ningrum, Suryadi, dkk. (2018). "Kajian Ujaran Kebencian di Media Sosial". Jurnal Ilmiah Korpus Vol. 2 No 3.

Nugraheni, Suci. (2017). Ujaran Kebencian Pada Wacana Debat Cagub Cawagub DKI Jakarta 2017 dan Implementasinya. Skripsi. Universitas Muhammadiyah Surakarta

Octaviani, Aulia. 2017. Ungkapan Kebencian pada Tuturan Heaters di Akun Instagram Basuki BTP dan Relevansinya Terhadap Pembelajaran Bahasa Indonesia di SMA. Skripsi. Universitas Muhammadiyah Surakarta.

Prima Angkupi. (2014). Kejahatan Melalui Media Sosial Elektronik di Indonesia Berdasarkan Peraturan Perundang-undangan Saat Ini. Jurnal MIKROTIK: Manajemen Informatika, Vol. 2, No.1.

R. Soesilo. (2013). Kitab Undang-undang Hukum Pidana (KUHP) serta Komentar-komentarnya Lengkap Pasal Demi Pasal. Bogor: Politeia.

Saifullah, Aceng Ruhendi. (2016). Analisis Teks Tanggapan Pengguna Internet Terhadap Teks Media Siber yang Berdampak Hukum (Kajian Linguistik Forensik Berbasis SemiotikPragmatik). Prosiding SETALI II: Universitas Pendidikan Indonesia.

Salutfiyanti, Delta Anggun. (2018). Analisis Ujaran Kebencian dalam Komentar Warganet Pada Akun Instagram Obrolan Politik. Skripsi. Universitas Muhammadiyah Malang.

Sari, Isnaini Desiana. (2019). "Ujaran Kebencian Pada Wacana Talk Show Indonesia Lawyers Club". Skripsi. Universitas Muhammadiyah Surakarta.

Subyantoro. (2019). Linguistik Forensik: Sumbangsih Kajian Bahasa dalam Penegakan Hukum. Jurnal Adil Indonesia, Vol. 1, No. 1. 
Syafyahya, Leni. (2018). Ujaran Kebencian dalam bahasa Indonesia: Kajian Bentuk dan Makna. Makalah Kongres KBI 2018: Universitas Andalas.

Ubaidillah. (2018). Tindak Tutur Direktif Ujaran Kebencian di Media Sosial di Indonesia. Tesis. Universitas Gadjah Mada.

Widodo, Lukman Aris. (2017). Ujaran Kebencian terhadap Pejabat Publik dalam Media Sosial: Kajian Pragmatik Pendekatan Gender. Tesis. Universitas Muhammadiyah Surakarta. 